\title{
Perancangan Aplikasi “Family Pass!" Sebagai Alat Bantu Dalam Pengasuhan Anak
}

\author{
Hermes Kelsun ${ }^{1}$, Desi Dwi Kristanto ${ }^{2}$ \\ ${ }^{1}$ Desain Komunikasi Visual, Universitas Pembangunan Jaya \\ Tangerang Selatan, Banten 15413, Indonesia \\ hermes.kelsun@student.upj.ac.id \\ ${ }^{2}$ Desain Komunikasi Visual, Universitas Pembangunan Jaya \\ Tangerang Selatan, Banten 15413, Indonesia \\ Email korespondensi: desi.dwikristanto@upj.ac.id
}

Received 21 March 2021, Revised 30 March 2021, Accepted 21 May 2021

\begin{abstract}
This research is intended to build a mobile application which is called "Family Pass!". This app is designed as a media and a tool to help parents in dealing with their parenting activities. Moreover, the Family Pass application enables parents to solve obstacles arising from globalization, for instance, the declining quality of the relationship between parents and children due to their parents' high demand for work. It is expected that by the existence of this parenting application, parents will be able to do parenting more optimally and effectively consequently, positive impacts are more achievable for both the children and the parents themselves.
\end{abstract}

Keywords: parenting, application, mobile apps, apps design

\begin{abstract}
Abstrak - Penelitian ini bertujuan untuk merancang sebuah aplikasi mobile bernama Family Pass, yang mana, aplikasi ini dibuat sebagai media dan sarana dalam membantu aktivitas pengasuhan terhadap anak. Aplikasi ini mencoba menyelesaikan masalah sosial yang timbul akibat globalisasi, yaitu meningkatnya tuntutan pekerjaan orang tua yang kemudian berdampak pada menurunnya tingkat kualitas kegiatan pengasuhan anak antara orang tua dan anak. Diharapkan dengan adanya aplikasi pengasuhan anak Family Pass ini, orang tua tetap dapat melakukan kegiatan pengasuhan secara lebih maksimal dan efektif sehingga dapat memberikan dampak positif untuk anak maupun orang tua itu sendiri.

Kata Kunci: pengasuhan, aplikasi, mobile apps, desain aplikasi
\end{abstract}

\section{PENDAHULUAN}

Keluarga merupakan pendidikan yang pertama dan utama dalam sejarah hidup seorang anak. Pendidikan dalam keluarga menjadi dasar penting dalam pembentukan karakter manusia itu sendiri. Untuk menciptakan karakter yang kuat dan jiwa baik pada anak di dalam keluarga, diperlukan terciptanya suasana keluarga yang harmonis dan dinamis, hal tersebut dapat tercipta jika terbangun koordinasi dan komunikasi dua arah yang kuat antara orang tua dan anak (Hyoscyamina, 2012).

Parenting atau ilmu pengasuhan anak modern mulai dikenal di Indonesia sejak awal tahun 1990-an. Parenting mencakup beragam aktivitas dengan tujuan agar anak mampu berkembang secara optimal dan bertahan hidup dengan baik. Maka, parenting meliputi pengasuhan fisik, emosi dan sosial.

Selain mencangkup tentang berbagai aktivitas yang berkaitan dengan tumbuh kembang anak, parenting juga memiliki keterkaitan dengan pengawasan terhadap anak itu sendiri. Pengawasan identik dengan kata controlling yang berarti "pengawasan, pemeriksaan". Dalam Kamus Umum Bahasa Indonesia (KUBI) pengawasan berarti: "penilik dan penjagaan". Barber membedakan antara pengawasan psikologis dan pengawasan perilaku. Pengawasan psikologis adalah upaya-upaya pengendalian yang bersifat memaksa terhadap perkembangan psikologis, emosi anak misalnya proses berpikir, pengungkapan diri, ekspresi emosi dan kedekatan pada orang tua. Pengawasan perilaku adalah upaya orang tua untuk mengatur dan mengelola perilaku anak (Lestari, 2016).

Di era globalisasi seperti sekarang ini, berbagai hal telah banyak berubah, gaya hidup masyarakat dan kebutuhan ekonomi berdampak pada tingginya tuntutan pekerjaan yang menyebabkan pasangan baru menikah menghabiskan waktu lebih banyak untuk bekerja dalam memenuhi kebutuhan hidup keluarganya. Hal ini berdampak pada terbatasnya waktu untuk melakukan kegiatan pengasuhan anak bagi pada keluarga muda. Berkurangnya intensitas dan efektivitas dari kegiatan pengasuhan anak oleh orang tua kepada anak tentu saja sangat disayangkan, mengingat kegiatan pengasuhan anak merupakan kegiatan yang memiliki banyak manfaat, baik untuk anak maupun orang tua itu sendiri.

Dari masalah sosial yang telah dipaparkan di atas, dapat mengetahui bahwa diperlukan sebuah media yang dapat menjembatani antara masalah 
efisiensi pengasuhan anak dengan kegiatan pengasuhan anak itu sendiri, oleh sebab itu penulis mencetuskan ide untuk membuat sebuah aplikasi pengasuhan anak bernama Family Pass sebagai media dan solusi permasalahan yang ada.

Dalam pembuatan aplikasi Family Pass ini, dibutuhkan proses penelitian untuk dapat memaksimalkan aplikasi yang akan dibuat. Penelitian dilakukan untuk mencari tahu perihal aktivitas apa saja yang sering dilakukan oleh orang tua maupun anak yang kemudian dapat dijadikan dasar perancangan aplikasi "Family Pass!" Dan Bagaimana desain aplikasi yang dapat mendukung dan menunjang kebutuhan akan kegiatan pengasuhan anak terhadap anak? Dengan tujuan untuk Merancang dan merealisasikan aplikasi "Family Pass!" Sebagai media pengasuhan anak orang tua kepada anak sekaligus menjadi solusi terhadap berbagai masalah yang ada di dalamnya. Metode penelitian yang digunakan dalam penelitian ini adalah metode penelitian campuran dengan teknik pengumpulan data meliputi studi literatur, wawancara ahli, observasi, studi perbandingan, dan penyebaran angket.

Setelah berbagai data didapatkan, proses selanjutnya adalah pengolahan data untuk mendapatkan berbagai kesimpulan mengenai masalah yang sedang diteliti. Hasil pengolahan berupa kesimpulan dan hasil analisa kemudian dijadikan sebagai acuan atau fondasi dasar dalam proses eksekusi karya. Data penelitian, hasil kesimpulan dan analisa serta proses perancangan hingga akhirnya menjadi sebuah karya atau produk dibahas dalam paparan ini.

\section{METODE PENELITIAN}

Metode pengumpulan data yang digunakan untuk mendukung penelitian ini adalah metode campuran dengan menggunakan teknik pengumpulan data yakni studi pustaka, wawancara, observasi, penyebaran angket, dan studi perbandingan.

Penelitian dilakukan dengan mempelajari bagaimana kegiatan mengasuh anak atau pengasuhan anak yang dilakukan pada pasangan suami istri yang baru mempunyai anak berusia antara tiga sampai tujuh tahun. Informasi tentang kegiatan pengasuhan anak juga diperoleh dari data sekunder berupa rangkuman wawancara dengan Dr. I Gusti Ayu Nyoman Pratiwi, seorang dokter spesialis anak.

Dalam penelitian ini, observasi dilakukan untuk mengetahui perilaku orang tua dan anak dalam konteks aktivitas pengasuhan anak. Dari observasi ini diperoleh informasi tentang hal-hal apa saja yang dapat mendukung dan menunjang aktivitas pengasuhan anak dan dapat diterapkan pada aplikasi yang sedang dibuat.

\section{Studi Perbandingan}

Teknik pengumpulan data menggunakan studi perbandingan dilakukan dengan cara menganalisis dan melakukan komparasi terhadap objek penelitian yang sudah ada sebelumnya untuk mendapatkan berbagai data terkait dengan objek penelitian itu sendiri, yang kemudian data hasil analisa serta komparasi yang telah didapat akan diolah kembali sampai akhirnya mendapat sebuah kesimpulan. Pada penelitian ini, studi perbandingan dilakukan dengan mengacu pada aplikasi pengasuhan anak yang telah beredar di masyarakat yaitu "Family5" dan "Parental Control".

Kedua aplikasi ini dipilih sebagai rujukan objek studi perbandingan mengacu pada faktor produktivitas kedua aplikasi tersebut, yang mana aplikasi "Family5" merupakan aplikasi yang paling sesuai dalam aspek fitur, sedangkan aplikasi "Parental Control" merupakan aplikasi pengasuhan anak dengan desain yang paling diminati olah para target pengguna. Analisa dan perbandingan yang dilakukan pada aspek fitur pengasuhan anak dan desain aplikasi itu sendiri.

\section{Penyebaran Angket}

Penyebaran angket ataupun biasa disebut dengan kuesioner merupakan teknik pengumpulan data yang dilakukan dengan cara memberikan formulir yang berisi pertanyaan seputar topik yang diteliti kepada responden. Dalam penelitian ini, teknik penyebaran angket digunakan untuk mencari data yang akan diolah sebagai data pelengkap dan penunjang data yang telah dikumpulkan sebelumnya dari proses wawancara dan observasi, sehingga data yang didapat akan semakin lengkap.

Penyebaran angket dilakukan sebanyak dua kali. Pertama dilakukan sebagai bagian dari riset pendahuluan untuk mempelajari bagaimana aktivitas pengasuhan anak pada target pengguna, dan yang kedua dilakukan untuk mempelajari bagaimana preferensi target pengguna dalam menggunakan sebuah aplikasi mobile. Selain itu juga untuk menguji kemudahan penggunaan dan keterbacaan pesan yang ditampilkan dalam aplikasi yang dirancang.

\section{Pengembangan Desain Aplikasi Mobile}

Pengembangan desain aplikasi mobile dilakukan dengan mempertimbangkan beberapa hal yaitu (1) simulasi aktivitas kegiatan pengasuhan anak, (2) pengaturan tata letak obyek grafis dalam aplikasi, (3) pemilihan huruf untuk keterbacaan pesan, (4) penggunaan warna untuk mencapai pengalaman pengguna yang optimal, dan citra aplikasi mobile sebagai aplikasi yang sesuai untuk digunakan oleh keluarga muda sebagai target pengguna.

\section{HASIL PENELITIAN DAN ANALISIS Pengasuhan Anak dalam Keluarga}

Data wawancara diperoleh melalui data sekunder yang mana pada data wawancara ini Dr. I Gusti Ayu Nyoman Pratiwi selaku dokter spesialis 
anak mengatakan bahwa secara umum pengasuhan anak merupakan kegiatan yang dilakukan bersama antara orang tua dan anak dengan tujuan agar anak dapat berkembang dengan baik dari sisi psikologis, fisik, dan pola pikir yang diterapkan pada setiap aktivitas yang dilakukan. Dr. Tiwi menyampaikan bahwa aktivitas pengasuhan anak dapat dilakukan dalam bentuk sederhana sampai yang ekstrem seperti bermain di lumpur bersama anak. Menurutnya walaupun dikatakan bahwa kegiatan seperti bermain lumpur merupakan kegiatan yang kotor untuk sebagian orang namun hal tersebut tidak menjadi masalah, karena yang perlu diperhatikan dalam setiap aktivitas pengasuhan anak adalah bagaimana orang tua dapat mendampingi anaknya dalam melakukan aktivitas pengasuhan anak.

Orang tua harus ikut sepenuhnya mendampingi anak dalam aktivitas pengasuhan anak karena aktivitas pengasuhan anak sangat bergantung pada seberapa intens kedekatan orang tua dan anak itu sendiri. Pada konsep utama, selain pentingnya kedekatan orang tua dan anak dalam kegiatan pengasuhan anak, hal lainnya yang perlu diperhatikan adalah tentang bagaimana setiap aktivitas yang dilakukan, anak dapat mendapatkan hak dan apa yang mereka butuh. Beliau juga menuturkan kegiatan pengasuhan anak yang baik adalah kegiatan yang setiap aktivitasnya dibarengi dengan stimulus pada setiap indra anak, mulai dari penciuman, perasa, dengar, dan lainnya. "Untuk waktu durasi pengasuhan anak, tidak ada acuan pasti. Bahkan 30 menit saja sudah cukup" tambahnya. Menurutnya bukan masalah waktu dari aktivitas yang dilakukan, namun lebih kepada seberapa bagus kualitas kebersamaan yang dapat diberikan oleh orang tua kepada anak pada saat melakukan aktivitas yang dijalani.

Pengasuhan anak merupakan sebuah aktivitas sederhana yang dapat dilakukan kapan pun dan di mana pun dengan tujuan untuk membantu memaksimalkan perkembangan anak secara menyeluruh. Dari wawancara ini juga diketahui bahwa aspek yang terpenting dari aktivitas pengasuhan anak ini adalah tentang kebersamaan orang tua dan anak tanpa terbatas oleh waktu sekalipun, karena hal yang juga harus diperhatikan adalah kualitas dari kebersamaan yang dilakukan dalam aktivitas pengasuhan anak itu sendiri. Sejalan dengan pemahaman terhadap aktivitas pengasuhan anak, pada studi literatur bab 2 telah diketahui bahwa anak memiliki kebutuhan dan haknya masingmasing, dan dari penjelasan Dr. Tiwi sebelumnya telah mengkonfirmasi bahwa aktivitas pengasuhan anak juga harus memperhatikan kebutuhan dan hak anak yang bersangkutan, agar anak juga dapat berkembang dengan lebih optimal.

Dalam melakukan kegiatan pengasuhan anak, kebanyakan dari para orang tua memilih aktivitas yang dapat dilakukan tanpa mengganggu mobilitas atau kegiatan dari orang tua itu sendiri namun tetap dapat memberikan intensitas yang baik untuk kedekatan antara orang tua dan anak seperti membaca buku cerita, bermain permainan sederhana, dan menonton bersama. Dari observasi pada video dokumenter ini juga dapat diketahui bahwa orang tua pada era globalisasi seperti sekarang ini cenderung memiliki pemahaman yang baik terhadap aktivitas pengasuhan anak. Namun sebaliknya, orang tua memiliki tantangan yang lebih kompleks dalam kaitannya dengan aktivitas pengasuhan anak, tuntutan pekerjaan dan aktivitas yang semakin tinggi membuat para orang tua tidak dapat meluangkan waktunya secara maksimal untuk beraktivitas bersama anak mereka. Hal ini kemudian membuat para orang tua mencari beragam aktivitas sederhana yang dapat dilakukan sambil menjalani aktivitas mereka sebagai alternatif. Aktivitas-aktivitas sederhana yang dilakukan seperti menggambar, bercerita, dan membaca ditujukan untuk dapat menyelaraskan dan menyeimbangkan antara konteks aktivitas pengasuhan anak dan aktivitas keseharian lainnya.

Walaupun pada dasarnya aktivitas yang dilakukan adalah aktivitas sederhana, para orang tua tetap mempertimbangkan faktor lain seperti intensitas hubungan mereka dengan sang anak, sehingga secara sederhana orang tua secara umum telah memilih aktivitas dan pola asuh yang telah disesuaikan dengan keperluan mereka agar anak tetap mendapatkan hak dan apa yang mereka butuh sejalan dengan apa yang telah penulis pelajari pada studi literatur.

Dari hasil pengumpulan data dengan menyebarkan kuesioner atau angket telah diketahui bahwa para orang tua telah memahami apa itu pengasuhan anak secara umum dan mereka juga telah menerapkan aktivitas ini sebagai salah satu kegiatan yang penting untuk dilakukan bersama anak mereka. Aktivitas pengasuhan anak yang sering dilakukan juga bervariasi dan kebanyakan dari aktivitas tersebut cenderung mengarah kepada kegiatan sederhana namun dapat mempererat hubungan orang tua dan anak secara spesifik dalam kaitannya dengan aktivitas pengasuhan anak seperti yang telah dijelaskan pada pemaparan data sebelumnya.

Namun faktanya aktivitas pengasuhan anak ini tidak bisa dilakukan secara maksimal, karena kebanyakan orang tua harus memenuhi tuntutan pekerjaan mereka, walaupun data menunjukkan sebagian besar orang tua mampu memberikan waktu bersama anak mereka dengan durasi tiga sampai delapan jam setiap harinya, namun ternyata tetap ada sebagian orang tua yang bahkan hanya bisa menghabiskan waktu bersama anak mereka dengan durasi kurang dari tiga jam sehari, hal ini tentu saja memprihatinkan mengingat dari data studi literatur telah diketahui bahwa anak pada usia 0-7 tahun membutuhkan perhatian orang tua dan interaksi 
secara intens untuk membantu perkembangan fisik, psikologis, dan cara berpikir anak itu sendiri.

\section{Aspek Desain dalam Perancangan Aplikasi Mobile}

Desain antarmuka pengguna antarmuka pengguna atau User Interface (UI) adalah suatu istilah yang digunakan untuk menggambarkan tampilan dari mesin atau komputer yang berinteraksi langsung dengan pengguna, secara tidak langsung dapat dipahami sebagai sampul terluar dari sebuah aplikasi ataupun web. Desain dan penyusunan tampilan antarmuka perlu diperhatikan untuk menghasilkan tampilan yang bagus (Ghiffary et al., 2018). Konsep utama dari desain grafis adalah teks dan gambar serta tata cara pengaturannya pada halaman, layar atau dalam sebuah bidang dan media yang ditujukan sebagai salah satu cara di mana orang dapat berkomunikasi di dunia modern. Elemen desain yang digunakan walaupun beraneka ragam tetapi tetap harus saling melengkapi untuk meningkatkan komunikasi atau kaidah visual secara keseluruhan (Ambrose \& Harris, 2009)

Ben Shneiderman (Shneiderman et al., 2009) menjelaskan bahwa para desainer mengenal delapan prinsip utama dalam mendesain user interface yang biasa sebutan "The Eight Golden Rules". Kedelapan prinsip tersebut adalah (1) Strive to Consistency. Prinsip ini mencangkup konsistensi dan menjelaskan kesamaan desain yang diterapkan pada setiap halaman agar pengguna dapat mengetahui keterkaitan antar satu halaman dengan halaman lainnya. Selain itu prinsip ini hal ini juga berperan penting dalam memperkuat tone and maner dari aplikasi yang akan dibuat. (2) Cater to Universal Usability. Prinsip ini menjelaskan berbagai tanda yang umum dan dapat diketahui serta dipahami oleh semua orang, dengan konteks, pemahaman pada aplikasi yang akan dibuat. (3) Offer Informative Feedback. Feedback atau umpan balik berperan penting dalam interaksi aplikasi dengan pengguna, namun pada dasarnya umpan balik yang baik tidak selalu berupa pesan atau notifikasi. Umpan balik yang baik bisa juga diciptakan dengan cara mengubah user interface dengan tujuan untuk membuat pengguna tahu bahwa tindakan dan apa yang mereka lakukan sudah direspons oleh aplikasi. (4) Design Dialogs to Yield Closure. Prinsip ini menganjurkan untuk tetap memberitahukan bahwa aplikasi telah merespons tindakan yang dilakukan oleh pengguna, sehingga pengguna tidak perlu menunggu atau melakukan langkah lainnya untuk menyelesaikan apa yang mereka inginkan. (5) Prevents Errors. Prinsip ini ditujukan sebagai bentuk pencegahan kesalahan yang dilakukan oleh pengguna dalam menjalankan proses dalam aplikasi, Poin ini biasanya berupa petunjuk, arahan, dan penjelasan dalam menyelesaikan proses pada aplikasi. (6) Permit Easy Reversal of Actions. Prinsip ini membuat pengguna menjadi lebih mudah untuk membatalkan tindakan mereka dan sekaligus memberikan mereka keleluasaan dalam mencoba serta menjelajah aplikasi tanpa khawatir menekan atau melakukan tindakan yang salah. Sebagai contoh umum dari penggunaan prinsip ini pada aplikasi adalah adanya tombol untuk kembali ke langkah sebelumnya. (7). Support Internal Locus of Control. Prinsip ini merupakan prinsip yang memberikan pengguna keleluasaan untuk mengatur aplikasi yang mereka gunakan, seperti tema, warna, maupun teks yang digunakan sesuai keinginan, karena pada dasarnya pengguna akan lebih nyaman dan senang menjelajahi aplikasi ketika mereka bisa mengubah antarmuka sesuai keinginan mereka. (8) Reduce Short-term Memory Load. Berdasarkan prinsip ini, sebuah aplikasi harus efektif dan tidak membuat pengguna melakukan kegiatan yang sama secara berulang-ulang. Sebagai contoh dalam aplikasi belanja daring, pengguna cukup mengisi data diri dan alamat sekali lalu dapat menyimpannya untuk digunakan kembali. Pengguna cukup mengeklik halhal yang mereka inginkan dan sistem akan memasukkan data pengguna secara otomatis pada halaman konfirmasi tanpa membuat pengguna memasukkannya lagi satu per satu.

Proses desain aplikasi mobile juga perlu mempertimbangkan aspek psikologis penggunanya. Dalam ruang lingkup desain media interaktif seperti aplikasi, pemanfaatan teori ini didasari pada hukum persepsi gestalt itu sendiri. Secara menyeluruh prinsip gestal berjumlah tidak kurang dari 114 hukum yang masing-masing berbeda antara yang satu dengan yang lainnya. Ayriza (2017) menyatakan bahwa secara umum hukum gestalt ini kemudian difokuskan menjadi lima hukum dasar yaitu (1) proximity, (2) similarity, (3) continuity, (4) closure, dan (5) figure/ground.

Proximity menjelaskan bahwa objek-objek yang berdekatan antara yang satu dengan yang lainnya akan dianggap sebagai sebuah unit dalam satu persepsi. Dengan demikian hal-hal yang saling berdekatan dalam waktu atau tempat akan cenderung dianggap sebagai suatu kesatuan.

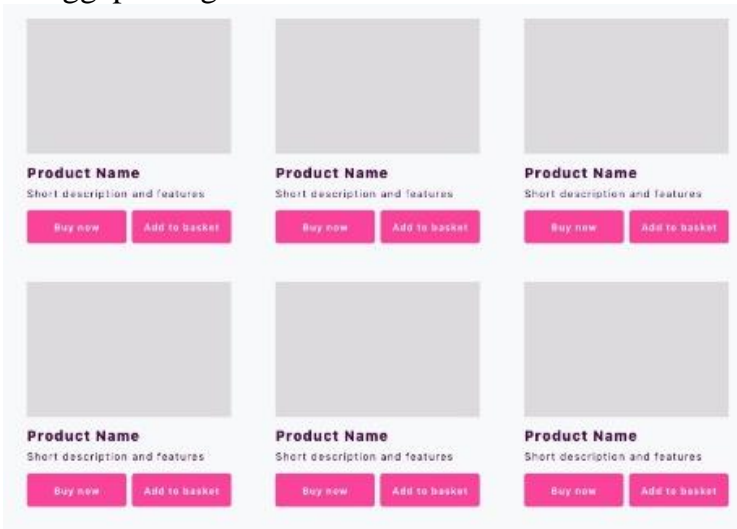

Gambar 1 Prinsip Proximity

Prinsip similarity menjelaskan bahwa halhal yang mirip satu sama lain, cenderung 
dipersepsikan sebagai suatu kelompok atau suatu unit. Dalam penerapannya pada media interaktif, setiap elemen visual yang memiliki kemiripan baik itu bentuk, warna, maupun ukuran akan dianggap sebagai satu bagian kelompok, hal ini tetap berlaku jika elemen visual tersebut terpisah secara spasial.

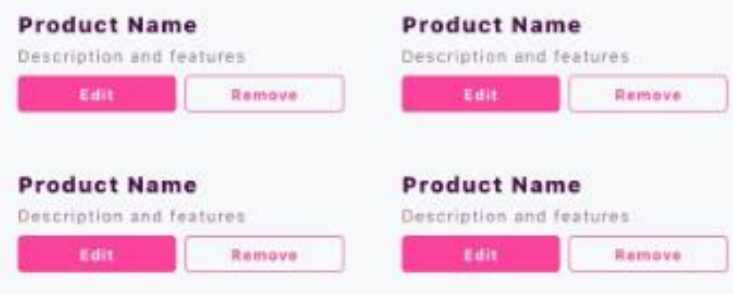

Gambar 2 Prinsip Similarity

Prinsip continuity menyatakan bahwa segala bentuk elemen-elemen yang tertata secara visual seolah-olah mengikuti garis lurus ataupun garis kurva halus yang selaras akan ditafsirkan sebagai sebuah satuan atau kelompok yang saling terkait atau terintegrasi. Pada konsep ini, penempatan elemenelemen tersebut nantinya akan mampu mengarahkan mata menuju arah tertentu.

\section{Home Services Contact}

Gambar 3 Prinsip Continuity

Prinsip closure menyatakan bahwa manusia memiliki tendensi untuk melengkapi dan mengisi pengalaman-pengalaman yang tidak lengkap, agar menjadi lebih berarti, secara sederhana hal-hal yang cenderung menutup akan membuat kesan totalitas tersendiri. Teori ini terjadi contohnya ketika kita melihat sebuah bentuk yang tidak utuh atau beberapa bagiannya tidak tertutup namun tetap dapat mengenali bentuk tersebut dengan mudah. Pada desain media interaktif prinsip ini dapat diterapkan pada perancangan ikon atau simbol.

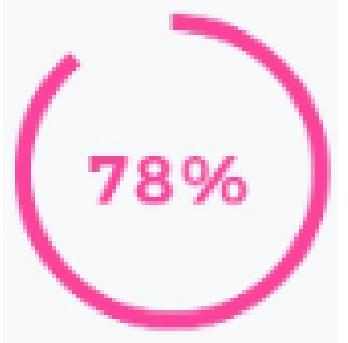

Gambar 4 Prinsip Closure

Prinsip figure and ground mengatakan bahwa suatu bidang persepsi dibagi menjadi suatu objek perhatian (figur) dan suatu bidang difusi yang merupakan latar belakang (background). Antara figur dan latar belakang itu saling berhubungan, tergantung perhatian, karena pada dasarnya ketika pengguna mengarahkan perhatian, yang akan pengguna lihat pertama kali adalah figure dan kemudian baru melihat background.

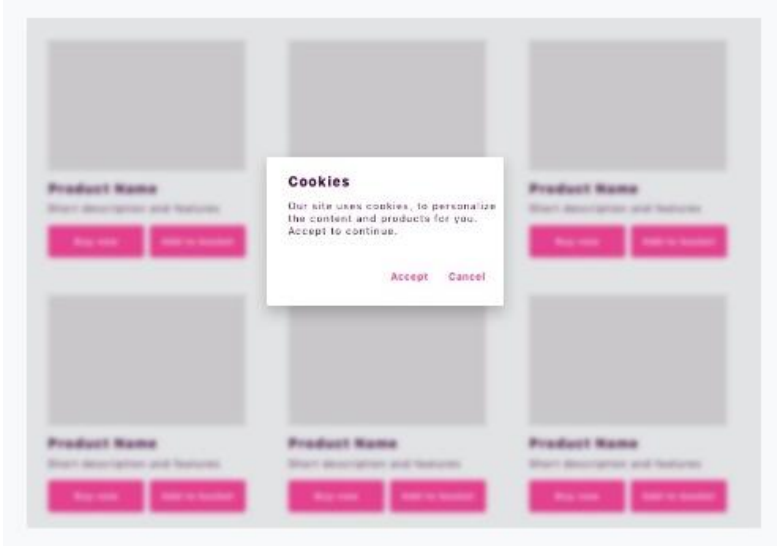

Gambar 5 Prinsip Figure and Ground

Warna merupakan salah satu komponen terpenting dalam sebuah desain aplikasi, pengaplikasian dan penggunaan warna itu sendiri terdiri dari header, teks, tombol, latar belakang dan elemen lainnya yang membentuk desain User Interface. Selain sebagai elemen estetika, dalam beberapa contoh kasus, warna kerap kali juga dikaitkan dengan identitas, citra, maupun ciri khas dari aplikasi yang akan dibuat (Cao et al., 2015).

Pada dasarnya, teori warna merupakan teori yang menghubungkan warna dengan kaitannya pada persepsi dan psikologi manusia, sama halnya dengan teori gestalt yang sudah dijelaskan sebelumnya, warna dapat mempengaruhi perasaan seseorang. Sebagai contoh saat seseorang melihat karya seni tertentu dengan warna yang berbeda-beda, secara tidak sadar alam bawah sadar orang tersebut akan memanipulasi emosi dengan sendirinya. Kemampuan memanipulasi emosi menggunakan warna juga kerap kali digunakan dalam proses pembuatan desain untuk mencapai tujuan tertentu.

Secara sederhana warna dibagi menjadi beberapa kelompok sesuai dengan persepsi yang ditimbulkan. Warna merah, jingga, dan kuning dikelompokkan sebagai warna hangat, warna biru dan ungu dikelompokkan sebagai warna dingin, yang terakhir adalah warna hitam, putih dan abu-abu yang dikelompokkan menjadi warna netral, namun tentu saja setiap warna sejatinya memiliki kemampuannya sendiri dalam membangun emosi dan citra.

Memahami cara penggabungan warna sama pentingnya dengan memahami setiap satu warna. Pemahaman tentang kecocokan warna merupakan pemahaman penting yang harus dipelajari dan dicermati untuk dapat menciptakan warna yang serasi dalam sebuah desain. Dalam menyusun warna, ada beberapa skema yang dapat digunakan. Skema 
tersebut antara lain skema (1) monochromatic, (2) analogus, (3) complementary, (4) triadic, (5) split complenetary, dan (6) rectangular triadic (Cao et al., 2015).

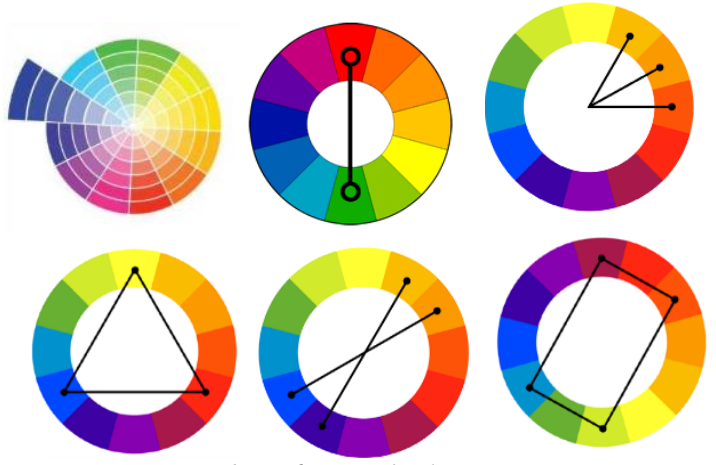

Gambar 6 Contoh Skema Warna

\section{Analisis Hasil Perbandingan}

Penelitian ini menggunakan aplikasi pengasuhan anak bernama "Family5" dan "Parental Control" yang tersedia di Google Playstore sebagai obyek referensi dengan analisis pada aspek fitur pengasuhan anak dan desain visual.

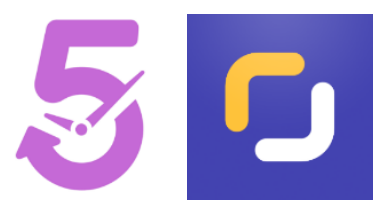

Gambar 7 Aplikasi "Family5" \& "Parental Control"

Dari segi pengasuhan anak, aplikasi "Family5" menawarkan berbagai macam fitur yang menggambarkan pengasuhan anak secara menyeluruh. Dalam konteks sederhana, aspek pengasuhan anak pada aplikasi ini dibagi menjadi tiga kategori yakni, activities, goals, dan situations. Masing-masing kategori memiliki berbagai macam kegiatan yang ditawarkan untuk dilakukan oleh orang tua dan anak. Setiap kegiatan pada suatu kategori aktivitas pun juga berbeda dari satu kategori dengan kategori yang lainnya, sehingga jumlah kegiatan yang dapat direkomendasikan aplikasi ini terbilang sangat lengkap, berbeda dengan aplikasi "Parental Control", aplikasi ini cenderung fokus pada aspek pengawasan orang tua terhadap anak mereka dalam konteks penggunaan gawai oleh anak, berbagai fitur pendukung kegiatan pengawasan ini diberikan untuk memberikan keleluasaan pada orang tua yang ingin mengawasi interaksi anak dengan gawai mereka..

Pada aspek desain, aplikasi "Family5" dan "Parental Control" memiliki konsep dan penerapan aspek desain yang ditujukan untuk kenyamanan pengguna saat mengoperasikan masing-masing aplikasi, mulai dari konsep warna, tipografi, dan jenis grid yang digunakan.

Warna yang digunakan pada aplikasi ini terbilang sangat cocok untuk digunakan pada desain aplikasi "Family5", pasalnya pengaplikasian skema warna analog ini ditujukan untuk memberikan tema tersendiri pada ketiga kategori aplikasi yang bersangkutan (activities, goals, dan situations), sedangkan pada aplikasi "Parental Control" penggunaan skema warna berjenis triadic diaplikasikan sehingga memberikan kontur warna seimbang pada aplikasi ini. Penggunaan skema warna triadic ini sesuai untuk diimplementasikan pada aplikasi "Parental Control" yang memang merupakan aplikasi dengan tingkat interaktif yang tinggi, sebagaimana sifat dari skema warna triadic itu sendiri yang dianggap paling aman untuk diterapkan pada media interaktif.

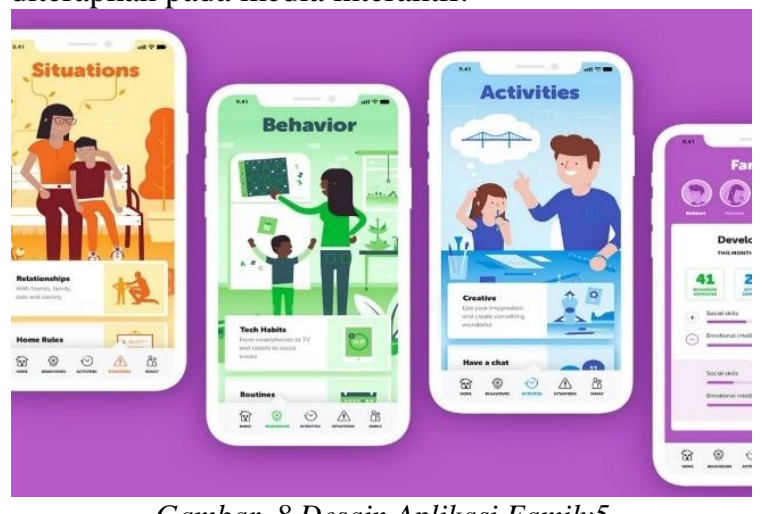

Gambar 8 Desain Aplikasi Family5

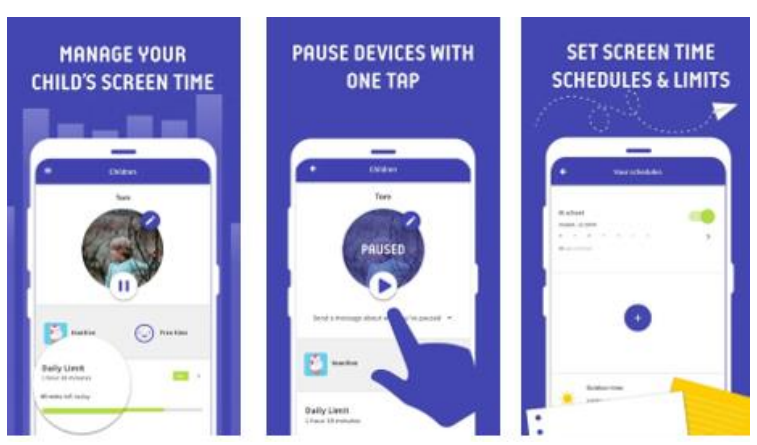

Gambar 9 Desain Aplikasi "Parental Control"

Aspek desain selanjutnya adalah tipografi, pada aplikasi "Family5" dan "Parental Control" keduanya menggunakan huruf berjenis san serif seperti pada umumnya, baik headline maupun pada bagian teks, semuanya menggunakan jenis huruf yang sama, perbedaan mendasar hanya terletak pada penekanan karakteristik hurufnya saja, dalam kasus ini penambahan karakteristik bold atau penebalan huruf dilakukan untuk membedakan konteks judul dan teks bacaan sehingga tercipta kolaborasi karakter huruf yang dinamis. Dari hasil studi literatur telah diketahui bahwa penggunaan huruf san serif memang merupakan pilihan yang tepat untuk diterapkan pada aplikasi ini, selain karakteristik huruf san serif yang sesuai dengan target pengguna, kejelasan dari teks yang ditampilkan juga memberikan nilai lebih pada kedua desain aplikasi ini.

Selain memiliki kesamaan pada aspek tipografi, kedua aplikasi ini juga memiliki kesamaan konsep 
pada penerapan sistem grid. Kedua aplikasi ini menggunakan sistem grid sederhana dan tidak terlalu kompleks, penataan sistem grid pada tata letak difokuskan untuk memberikan kesan simpel namun tetap teratur. Selain ditujukan untuk mempermudah pemahaman pengguna terhadap desain user interface, penerapan sistem grid yang simpel ini juga ditujukan agar pengguna mudah mengoperasikan aplikasi ini dengan meningkatkan faktor user experience. Hal ini penting karena target pengguna dari aplikasi ini mencakup kelompok orang tua dan juga anak-anak.

\section{Penerapan Pada Desain Akhir Karya}

Setelah melakukan penelitian dan mendapatkan kesimpulan serta pengetahuan terkait pengasuhan anak dan aplikasi itu sendiri, langkah selanjutnya adalah menyiapkan dan membentuk strategi pendukung terkait perancangan aplikasi Family Pass, dengan mengacu pada pengetahuan serta data yang telah diperoleh, diolah dan dikaji.

Pada aspek fitur aktivitas pengasuhan anak, tersedia berbagai kegiatan yang kemudian dipetakan dalam berbagai kategori pilihan aktivitas sesuai kebutuhan para orang tua. Selain itu, untuk mendukung aktivitas pengasuhan anak antara orang tua dan anak tersedia berbagai fitur lainnya seperti penyesuaian umur anak untuk mendapatkan aktivitas yang sesuai.

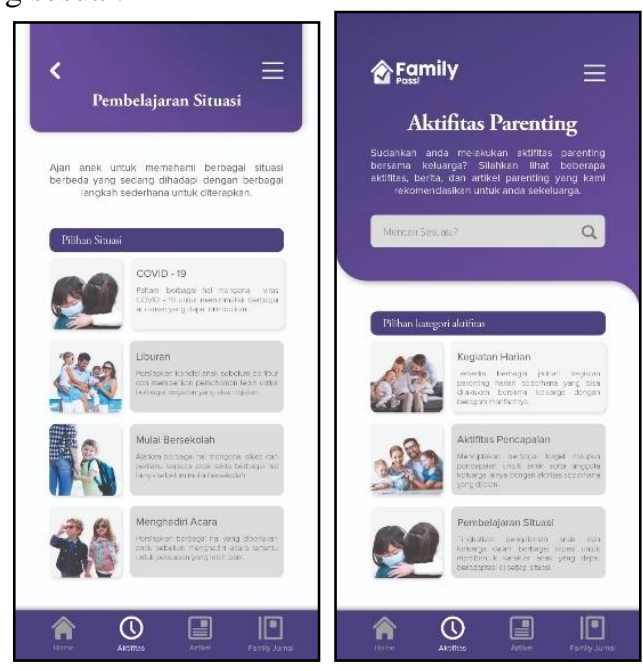

Gambar 10 Pilihan Fitur Aplikasi Family Pass

Berbagai informasi dan berita terkait dunia pengasuhan anak yang dapat diakses dengan mudah oleh orang tua, tersedia pula fitur jurnal, kontak darurat, sampai pada fitur yang dapat menghubungkan orang tua dengan para pakar pengasuhan anak yang dapat membantu orang tua dalam melakukan aktivitas pengasuhan anak itu sendiri, selain itu tidak lupa disediakan fitur penilaian dan review yang kemudian hasilnya dapat disimpan dalam kolom jurnal yang tersedia, hal ini ditujukan agar orang tua dapat menilai dan melakukan evaluasi terhadap kegiatan yang telah dijalani.
Untuk pemilihan warna yang akan diaplikasikan pada aplikasi Family Pass mengacu pada prinsip skema warna analog. Penggunaan skema warna ini selain merupakan skema warna yang disukai oleh para pengguna, penerapannya pun terbilang sangat mudah dan efisien. Selain itu, keseimbangan warna pada skema analog juga merupakan salah satu alasan dipilihnya skema warna ini, dengan penerapan komposisi warna yang seimbang pada aplikasi tentunya dapat memberikan nilai lebih dalam menarik perhatian pengguna. Dari segi user experience skema warna ini juga dapat memberikan kemudahan penyampaian informasi dan kejelasan konten dari aplikasi yang akan dibuat.

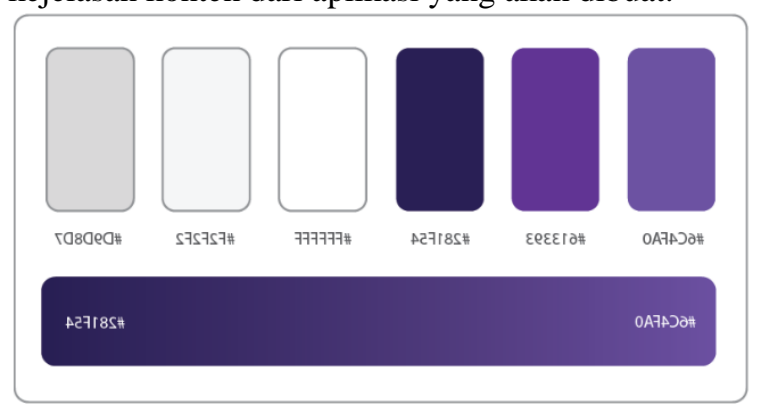

Gambar 11 Warna yang Digunakan pada Aplikasi Family Pass

Pemilihan jenis huruf untuk aplikasi pengasuhan anak Family Pass akan mengacu pada konsep yang telah dipaparkan yaitu memadukan penggunaan jenis huruf serif dan san serif. Perpaduan ini dilakukan dengan menggunakan huruf untuk membedakan bagian-bagian yang ada. Sebagai contoh pada headline dan body text, huruf yang digunakan adalah Adobe Garamond Pro dan Proxima Nova. Kedua huruf ini dapat mewakili konsep sederhana dan elegan dengan tingkat keterbacaan dan kejelasan yang baik, sehingga dapat memberikan kenyamanan kepada para pengguna saat membaca maupun mengoperasikan aplikasi Family Pass itu sendiri. Berbagai informasi dan berita terkait dunia pengasuhan anak yang dapat diakses dengan mudah oleh orang tua, tersedia pula fitur jurnal, kontak darurat, sampai pada fitur.

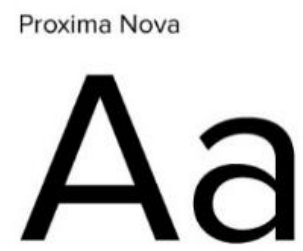

ABCDEFGHIJ abcdefghij KLMNOPQRS kImnopqrs TUVWXYZ turwXYZ

Adobe Garamond Pro

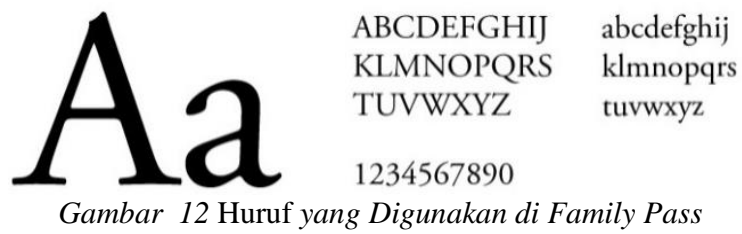


Aspek desain lainya yaitu penempatan atau tata letak dalam desain aplikasi Family Pass diatur menggunakan sistem grid dengan komposisi enam kolom. Penggunaan sistem grid 6 kolom pada aplikasi Family Pass didasarkan kepada fungsi utama dari grid 6 kolom itu sendiri, yaitu untuk menciptakan kesederhanaan dan mempermudah pengaturan elemen-elemen visual pada desain User Interface yang akan dibuat. Tidak hanya itu, penggunaan sistem grid 6 kolom ditujukan agar pengguna dapat berinteraksi dengan aplikasi secara lebih efektif dan lebih mudah sehingga aplikasi Family Pass dapat memaksimalkan prinsip User Experience dengan lebih baik, dan berikut beberapa hasil desain untuk aplikasi "Family Pass!" yang telah dibuat.

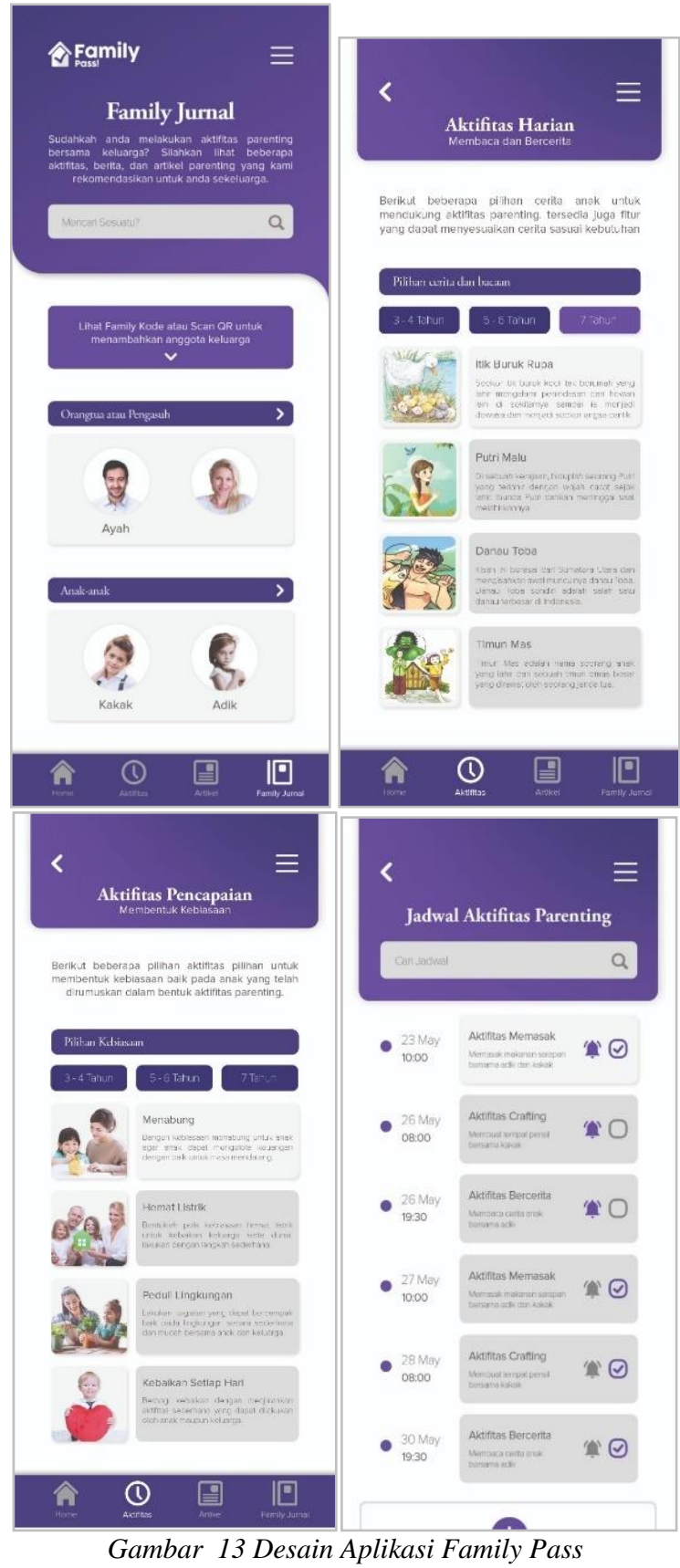

\section{KESIMPULAN}

Pada dasarnya pengasuhan anak merupakan salah satu aspek penting dalam membentuk generasi yang unggul dan berdaya saing, pengasuhan anak sendiri dapat disimpulkan sebagai sebuah aktivitas pengembangan diri seorang anak lewat berbagai kegiatan pengasuhan yang dilakukan secara tepat bersama orang tua mereka. Secara sederhana tujuan dari aktivitas pengasuhan anak ini adalah untuk membantu tumbuh kembang anak dari aspek psikologis, fisik, sampai tingkah laku.

Dari berbagai data yang telah dipaparkan dan telah dianalisis, peneliti dapat menarik sebuah kesimpulan bahwa aktivitas pengasuhan anak dapat dilakukan dengan mudah di mana saja dan kapan saja, bahkan aktivitas sederhana seperti membaca buku cerita bersama anak, menggambar, maupun melakukan hanya sekedar bersenda gurau dapat dikatakan sebagai aktivitas pengasuhan anak selama aktivitas yang dilakukan dapat memberikan pembelajaran kepada anak dan mempererat intensitas hubungan antara orang tua dan anak.

Dari penelitian yang telah dilakukan peneliti dapat menyimpulkan bahwa dalam membuat desain media interaktif pematangan konsep desain dan uji penggunaan merupakan hal yang sangat penting untuk dilakukan, sebelum dan sesudah desain dibuat. Dari penelitian ini telah diketahui bahwa berbagai aspek desain seperti penggunaan warna, pemilihan jenis huruf, dan ketentuan grid atau tata letak sangat berpengaruh terhadap respons dan kenyamanan pengguna dalam mengoperasikan sebuah aplikasi, namun hal tersebut tentu saja belum dapat dikatakan baik tanpa melalui proses pengujian penggunaan lebih lanjut. Pengujian lanjutan ini diperlukan guna mengetahui berbagai tanggapan dari pengguna terhadap desain aplikasi itu sendiri sehingga segala aspek pada aplikasi seperti user interface maupun user experience dapat lebih dimaksimalkan (Shneiderman et al., 2009).

\section{PENGAKUAN}

Dalam melakukan penelitian ini beberapa data didapatkan melalui sumber pendukung. Hal ini disebabkan oleh terhambatnya proses penelitian karena situasi dan kondisi lapangan yang tidak memungkinkan saat penelitian ini dilakukan. Penyebaran wabah virus COVID-19 menyebabkan proses penelitian tidak bisa dilakukan secara maksimal, khususnya untuk pengumpulan data wawancara dan observasi. Oleh sebab itu, penggunaan data sekunder dilakukan untuk melengkapi data wawancara dan observasi yang diperlukan.

Data wawancara didapatkan lewat sebuah video dokumenter yang dipublikasikan oleh Harjono Halim pada platform Youtube pada tanggal 12 September 2011. Pada video tersebut Dr. I Gusti Ayu Nyoman Pratiwi melakukan penjelasan materi dan tanya jawab dengan topik "Natural \& Conscious 
Pengasuhan anak". Selain data wawancara, data observasi juga didapatkan dengan melakukan cara yang sama, yakni dengan mengamati dan menganalisis video yang dibagikan tentang pengalaman kegiatan pengasuhan anak para orang tua yang dipublikasikan oleh sebuah lembaga keluarga yang bernama Smart Mama, sehingga peneliti tetap dapat mengetahui gambaran kegiatan pengasuhan anak para orang tua secara nyata.

\section{DAFTAR PUSTAKA}

Ambrose, G., \& Harris, P. (2009). The Fundamentals of Graphic Design. In The Fundamentals of Graphic Design. https://doi.org/10.5040/9782940476008

Cao, J., Zieba, K., Stryjewski, K., \& Ellis, M. (2015). Color Theory in Web UI Design: A Practical Approach to the Principles. UXPin Inc. https://www.uxpin.com/studio/ebooks/color-theoryweb-ui-design-practical-principles/

Ghiffary, M. N. El, Susanto, T. D., \& Prabowo, A. H. (2018). Analisis Komponen Desain Layout, Warna, dan Kontrol pada Antarmuka Pengguna Aplikasi Mobile Berdasarkan Kemudahan Penggunaan (Studi Kasus: Aplikasi Olride). Jurnal Teknik ITS, 7(1), A143-A148. https://doi.org/10.12962/j23373539.v7i1.28723

Hyoscyamina, D. E. (2012). Peran Keluarga Dalam Membangun Karakter Anak. Jurnal Psikologi; Vol 10, No 2 (2011): Oktober 2011. https://doi.org/10.14710/jpu.10.2.144-152

Lestari, S. (2016). Psikologi Keluarga: Penanaman Nilai dan Penanaman Konflik Dalam Keluarga. Prenada Media.

https://books.google.co.id/books?id=4VDODwAAQ BAJ

Shneiderman, B., Plaisant, C., Cohen, M. S., \& Jacobs, S. M. (2009). Designing the User Interface. Information Design Journal, 17(2), 157-158. https://doi.org/https://doi.org/10.1075/idj.17.2.14ma r 